MATERIAŁY

STUDIA NORWIDIANA 38:2020

DOI: https://doi.org/10.18290/sn.2038-10

TOMASZ KORPYSZ

\title{
NIEPUBLIKOWANA PODOBIZNA ORYGINAŁU AKTU URODZENIA CYPRIANA NORWIDA
}

Kończąc swój artykuł Ślady Norwidów w Dąbrówce, Waldemar Pałys konkludował: „Przedstawione dokumenty to, jak się wydaje, wszystkie zachowane ślady o Norwidach w rodzinnej parafii Cypriana Norwida"1. Po ponad piętnastu latach konieczne okazuje się zweryfikowanie tego twierdzenia. I to z dwóch powodów. Po pierwsze, w 2007 r. powstało Archiwum Diecezjalne Warszawsko-Praskie, które gromadzi dokumenty z parafii tejże diecezji i do którego trafiły także przywoływane przez autora księgi parafialne z Dąbrówki. Po drugie, jak się ostatnio okazało, w rękach prywatnych jednego z mieszkańców gminy Dąbrówka znajduje się niewielka część dużo wcześniej rozproszonego archiwum parafii, w tym jeden dokument, który jest szczególnie interesujący dla norwidologów.

W poświęconym Pamięci C. Norwida VIII tomie Chimery Zenon Przesmycki pisał:

We wspominanej tylekroć puściźnie bezpośredniej po C. Norwidzie, którą powierzył nam łaskawie p. W Gasztowt, odnaleźliśmy zwitek dokumentów osobistych poety, składający się: 1) z malowanego na pergaminie „Excerpttu (sic) Genealogij Starożytnego Domu Urodzonych Norwidów", wydanego stronie rekwirującej w r. 1811 z ksiąg genealogicznych deputacyi wywodowej szlacheckiej gubernii Mińskiej; 2) z notatki rękopiśmiennej, stwierdzającej przynależność Jana Norwida (ojca poety), w charakterze brata trzeciego stopnia, do jednej (de l'Aigłe Blanc) z 23 lóż masońskich, zależnych od Wielkiej Loży Asstrée à l'O w Petersburgu; 3) z oryginalnej atestacyi bierzmowania, udzielonego poecie, $\mathrm{z}$ nadaniem imienia Kamil, przez kardynała Franzoniego w Rzymie r. 1845 (,,patrinus fuit Illmus D. Carolus Comes Krasiński"); i w reszcie 4) z metryki poety stwierdzającej nakoniec autentyczną datę jego urodzin (d. 24 września 1821 r.) $)^{2}$ oraz ze sporządzonego widocznie do użytku za granicą,

${ }^{1}$ W. PAŁYS, Ślady Norwidów w Dąbrówce, „Studia Norwidiana” 20-21: 2002-2003, s. 166.

${ }^{2}$ Sformułowana nie bez satysfakcji uwaga Miriama, że cytowany niżej dokument rozstrzyga „nakoniec” (czyli 'nareszcie') kwestię daty urodzin poety, wynika z rozbieżności pojawiających się w dostępnych wówczas źródłach. Różne daty podawane są chociażby w nekrologach publikowanych po śmierci Cypriana Norwida. Autor nekrologu z „Dziennika Poznańskiego” (nr 119, 
ale niepoświadczonego urzędownie, francuzkiego przekładu tegoż dokumentu. Wypis ów metryczny, sporządzony na „papierze pod stempel”, z wodnemi znakami i pieczęcią stemplową, w całkowitem brzmieniu tu pomieszczamy:

Gubernia Warszawska (Znak stemplowy 7 1⁄2 kopiejki) Powiat Stanisławowski

Wyciąg z Ksiąg Urodzeń Kościoła Parafii Dąbrówka.

Nr 86. Karta 19. Wieś Głuchy. — Roku tysiąc ośmset dwudziestego pierwszego dnia pierwszego Października o godzinie dziesiątej rano — przed nami Xiędzem Janem Kantym Matlińskim Proboszczem Dąbrowskim Urzędnikiem Cywilnym w gminie Dąbrówka powiecie Stanisławowskim Województwie Mazowieckiem, stawił się JWielmożny Jan Norwid, mający lat trzydzieści siedm, Kawaler Maltański, Dziedzic majętności Laskowo Głuchy, tamże zamieszkały, i okazał nam dziecię płci męskiej, które urodziło się na dniu dwudziestym czwartym zeszłego miesiąca o godzinie ósmej w wieczór w Laskowie Głuchach w domu jego własnym pod N. pierwszym, oświadczając, że jest spłodzone z niego i Wielmożnej Ludwiki Zdzieborskiéj, mającéj lat dwadzieścia dwa, Jego małżonki, i że życzeniem ich jest nadać mu imiona Cypryan, Xawery, Gierard i Walenty. - Po uczynieniu powyższego oświadczenia i okazaniu dziecięcia w przytomności Jaśnie Wielmożnych Cypryana Szukiewicza, mającego lat czterdzieści jeden, Prezesa Sądów Apellacyjnych Grodzińskich, zamieszkałego w Warszawie, i Xawerego Dybowskiego, mającego lat pięćdziesiąt, Marszałka powiatu Węgrowskiego i Dziedzica Dóbr Dębinek i Ceranowa, zamieszkałego w Dębinkach — Akt niniejszy stawającym przeczytaliśmy i z Ojcem dziecięcia oraz dwoma świadkami podpisaliśmy. — Jan

29 maja 1883 r.) przyznaje: „Dokładnej daty urodzenia nieboszczyka nie mogliśmy się od nikogo dowiedzieć, że jednak wszyscy mniej więcej zgadzają się, że mógł teraz mieć sześćdziesiąt i parę lat, urodzić się więc musiał około 1820 r.” (cyt. za: Z. TroJANOWICZOWA, E. LiJEWSKA, Kalendarz życia i twórczości Cypriana Norwida, t. II: 1861-1883, s. 785). Z kolei w nekrologach z „Gazety Warszawskiej” (nr 120, 2 czerwca 1883 r.) oraz „Roli” (nr 23, 9 czerwca 1883 r.) podany jest rok 1825 (zob. tamże, s. 791, 793). W kilku innych nekrologach pada informacja, że poeta $\mathrm{w}$ chwili śmierci miał 59 lat, co datę urodzin przesuwa na rok 1824 (zob. tamże, s. 787, 792, 796). Z kolei „Kurier Paryski” (15 czerwca 1883 r.) informował o projekcie nagrobka, który mieli wystawić Norwidowi mieszkańcy Domu Św. Kazimierza, i przytaczał projekt inskrypcji nagrobnej podającej rok 1822 (zob. tamże, s. 764). Dwa opublikowane za życia poety biogramy z Brockhaus Konversations-Lexicon oraz Grand Dictionnaire Universel du XIX ${ }^{e}$ siècle Pierre'a Larousse'a - podawały natomiast rok 1842 (zob. tamże, s. 330-331, 551). Na ten sam rok wskazuje ponadto list Elizy Thiébault Lubomirskiej do Norwida, w którym komentowała ona przekroczenie przez niego „nieszczęsnego Rubikonu 40 lat” (zob. tamże, s. 202). Juliusz Wiktor Gomulicki zauważa, że list ten to „interesujące echo jego [tj. Norwida] mitu osobistego” (J.W. GoMULICKI, Addenda et corrigenda, [w:] PWsz XI, s. 608. Nawiązuje tu, rzecz jasna, do znanego zdania z [Autobiografii artystycznej]: „Przyszedł na świat w Mazowszu we wsi dziedzicznej zwanej Laskowo, o mil parę od Warszawy, czasu kiedy w Grecji umierał Noël Byron, i z tych dwóch spółczesnych zdarzeń nie wie dotąd, które jest smętniejszym?!” (PWsz VI, 556), w którym sam poeta łączył datę swoich narodzin $\mathrm{z}$ datą śmierci Byrona, a więc rokiem 1842. Echa tego autokreacyjnego „mitu osobistego" widoczne są w niektórych przywoływanych wyżej źródłach, znacząco wpłynęły one także na stan wiedzy pierwszych norwidologów, w tym Zenona Przesmyckiego. 
Norwid - Cypryan Szukiewicz — Xawery Dybowski - Xiądz Jan Kanty Matliński Proboszcz Dąbrowski. -

Za zgodność niniejszego wypisu z właściwą Księgą Kościoła świadczę w Dąbrówce dnia 29 kwietnia 1846 r. —

Xsiądz Fr. Zamaszewski Wik. P. D. ${ }^{3}$

Jak widać, Przesmycki - mimo że początkowo pisze o „metryce poety” dysponował jedynie jej odpisem z roku 1846 i to ten odpis cytuje. Fotokopię tego samego dokumentu po latach opublikował Juliusz Wiktor Gomulicki w ostatnim tomie Pism wszystkich ${ }^{4}$, a także w osobnym wydaniu encyklopedycznej części tego tomu ${ }^{5}$. Co ciekawe, zarówno w podpisie pod ilustracjami, jak i w dziale Dokumentacja ilustracyjna. Objaśnienia edytor tytułuje dokument jako „Świadectwo urodzenia Cypriana Norwida, 1821", , choć w dalszym komentarzu dodaje już właściwą nazwę: „Wyciąg z Ksiąg Urodzeń Kościoła Parafii Dąbrówka” i wyjaśnia, że wyciąg ten został „sporządzony na życzenie poety, który przebywał wtedy w Berlinie i załatwiał różne formalności paszportowe" ${ }^{\text {" }}$. Prawdopodobną przesłankę do wyjaśnienia tej nieco zaskakującej niespójności można wyczytać z dokładnej lektury tekstu dokumentu umieszczonego pod tytułem Świadectwo urodzenia Cypriana Norwida w Kalendarzu biograficznym Cypriana Norwida w tym samym XI tomie edycji Pism wszystkich:

Głu c hy . - Roku tysiąc ośmset dwudziestego pierwszego, dnia pierwszego października, o godzinie dziesiątej rano, przed nami: księdzem Janem Kantym Matlińskim, proboszczem dąbrowskim, urzędnikiem cywilnym w gminie Dąbrówka, powiecie Stanisławowskim, województwie Mazowieckiem, stawił się JWielmożny Jan Norwid, mający lat trzydzieści siedem, kawaler maltański, dziedzic majętności Laskowo-Głuchy, tamże zamieszkały, i okazał nam dziecię płci męskiej, które urodziło się na dniu dwudziestym czwartym zeszłego miesiąca o godzinie ósmej w wieczór, w Laskowie Głuchach, w domu jego własnym pod numerem pierwszym, oświadczając, że jest spłodzone z niego i Wielmożnej Ludwiki Zdzieborskiej,

${ }^{3}$ Z. P. [Zenon Przesmycki], Z notat i dokumentów o C. Norwidzie, „Chimera” 8(1904), z. 22/23/24, s. 437-438. Dokument znajduje się obecnie w Bibliotece Narodowej: Rps 6293 IV.

${ }^{4}$ Zob. PWsz XI, il. 3-4. Wcześniej Gomulicki jedynie opisywał dokument w katalogu wystawy z 1946 r. - zob. Cyprian Norwid. Wystawa w 125 rocznicę urodzin. Katalog, Warszawa 1946, poz. 5, s. 10 .

${ }^{5}$ Zob. J.W. GomUlicki, Cyprian Norwid. Przewodnik po życiu i twórczości, Warszawa 1976.

${ }^{6}$ Zob. PWsz XI, 328. Fałszywie też uznaje widniejący na dokumencie numer 86 za numer wyciągu, choć $\mathrm{w}$ rzeczywistości jest to numer aktu urodzenia poety.

${ }^{7}$ Tamże. W przypisach do tekstu dokumentu Gomulicki odsyła do fotokopii słowami: „Zob. podobiznę tego świadectwa, które poeta woził ze sobą po świecie: il. 3 i 4 (oraz obj.)” (PWsz XI, 159). 
mającej lat dwadzieścia dwa, jego małżonki, i że życzeniem ich jest nadać mu imiona Cyprian, Ksawery, Gierard i Walenty.

Po uczynieniu powyższego oświadczenia i okazaniu dziecięcia w przytomności Jaśnie Wielmożnych Cypriana Szukiewicza, mającego lat czterdzieści jeden, prezesa sądów apelacyjnych grodzieńskich i różnych orderów kawalera, zamieszkałego w Warszawie, i Ksawerego Dybowskiego, mającego lat pięćdziesiąt, marszałka powiatu węgrowskiego i dziedzica dóbr Dembinek i Ceranowa, zamieszkałego w Dembinkach, akt niniejszy stawającym przeczytaliśmy i z ojcem dziecięcia oraz dwoma świadkami podpisaliśmy.

Jan Norwid - Cyprian Szukiewicz - Xawery Dybowski - Jan Kanty Matliński, Prob[oszcz] Dąbr[owski], U[rzędnik] cywilny (PWsz XI, 26-28).

Większość różnic między przywołany wcześniej tekstem w edycji Przesmyckiego a tekstem w edycji Gomulickiego wynika z oczywistego uwspółcześnienia zasad ortografii (zwłaszcza pisowni wielką i małą literą) oraz interpunkcji, jednakże pięć ma inny charakter. Mniej istotne są: zmiana zapisu nazwy siedziby parafii z „Dębinki” na „Dembinki” oraz pominięcie słowa „ksiądz” przy imieniu i nazwisku „Jan Kanty Matliński” w liście osób popisujących akt, pozostałe trzy są znacznie ważniejsze i bardzo symptomatyczne.

Gomulicki po pierwsze, charakterystykę Cypriana Szukiewicza poszerza o wyrażenie ,i różnych orderów kawalera”, po drugie, w podpisach zaznacza i rozwija trzy skróty („Prob[oszcz]”, „Dąbr[owski]”, „U[rzędnik]”), a po trzecie, dokument w jego wersji kończy się określeniem ówczesnej urzędowej funkcji ks. Matlińskiego jako proboszcza, czyli „urzędnik cywilny”. W tekście drukowanym w Chimerze tych elementów nie ma, co więcej: próżno ich szukać na fotokopii odpisu, ich pominięcie nie było zatem błędem Miriama, który z tego właśnie odpisu korzystal ${ }^{8}$. Tak daleko idące (choć nieliczne) różnice trudno uznać za zwykłe pomyłki możliwe podczas kopiowania dokumentów. Ich przyczyna musi być zupełnie inna: Gomulicki najprawdopodobniej widział jakiś inny dokument lub też jego wierny odpis. Być może dysponował nim wcześniej, a w czasie przygotowywania Pism wszystkich do druku już nie (archiwum parafialne kilkakrotnie

\footnotetext{
${ }^{8}$ Co ciekawe, autorki kalendarium życia i twórczości Norwida, które cytują fragmenty omawianego dokumentu, deklarują wprawdzie, że publikują je za edycją Przesmyckiego, ale w rzeczywistości korzystają z obu wersji, kompilując rozwiązania Miriama i Gomulickiego i wprowadzając własne modyfikacje. Przykładowo: jak Przesmycki - stosują w wykazie osób podpisujących dokument rzeczownik „ksiądz”, jak Gomulicki - wprowadzają charakterystykę Szukiewicza jako „orderów różnych kawalera” i na koniec dodają wyrażenie „urzędnik cywilny”, ale już opuszczają w nim znaki skrótów, a we wcześniejszym tekście kilkakrotnie zmieniają pisownię wielką i małą literą (jedynie omyłką drukarską jest zapewne „stawiającym” zamiast „stawającym” we frazie: „akt niniejszy stawiającym [sic!] przeczytaliśmy”). Zob. Z. TROJANOwICZOWA, Z. DAMBEK, Kalendarz życia i twórczości Cypriana Norwida, tom I: 1821-1860, Poznań 2007, s. 3-4.
} 
ulegało rozproszeniu i częściowemu zniszczeniu), dlatego też ostatecznie opublikował tekst w kilku miejscach różniący się od tekstu widocznego na umieszczonej w Pismach wszystkich fotokopii odpisu. Hipotezę powyższą potwierdza szczęśliwie zachowany w rękach prywatnych oryginał aktu urodzenia poety.

Dokument znajduje się w nieco zniszczonym poszycie będącym obszerną częścią księgi akt stanu cywilnego parafii Dąbrówka z roku 1821. Zachowany fragment rozpoczyna się od aktu $\mathrm{nr} 68 \mathrm{z}$ czerwca tego roku, na górze tej strony widnieje współczesny dopisek czerwonym i częściowo niebieskim długopisem: „1821” (zob. il. 1). Strona z aktem urodzenia poety ma nieco zniszczone brzegi i jest częściowo zaplamiona atramentem, ale tekst pozostaje całkowicie czytelny (zob. il. 2). Zwraca uwagę bardzo staranne i ozdobne pismo: dokument - w przeciwieństwie do większości w tej księdze - został w całości napisany własnoręcznie przez proboszcza ks. Jana Kantego Matlińskiego (wskazuje na to porównanie charakteru pisma z licznymi podpisami ks. Matlińskiego pod sporządzonymi przez inne osoby aktami na sąsiednich stronach). Rzecz jasna, widnieją na nim także własnoręczne podpisy wszystkich przybyłych, w tym ojca poety - Jana; w przypadku wielu innych aktów jest inaczej, a podpis proboszcza poprzedzony jest formułą: „Akt niniejszy stawającym przeczytaliśmy i gdy ci pisać nie umieją, podpisaliśmy" (zob. il. 3 akt 83 i 84 oraz il. 2. akt 87).

Dokładna lektura prezentowanego oryginalnego aktu urodzenia dowodzi, że właśnie na nim opiera się tekst opublikowany przez Gomulickiego. Edytor wprawdzie uwspółcześnił ortografię i interpunkcję i niesłusznie połączył inicjalną formułę datacyjną z pierwszym zdaniem, pominął też słowo „ksiądz” (zapisane skrótem jako „X”) przy podpisie proboszcza, jednak wszystkie wymienione wyżej istotne odmienności od tekstu znanego z edycji Przesmyckiego znajdują tu potwierdzenie. Wartą zauważenia ciekawostką jest odnoszący się do Cypriana Szukiewicza dopisek na marginesie „i różnych orderów kawaler”, opatrzony parafą (w postaci samego nazwiska) ks. Matlińskiego. Jak widać, formuła ta została dopisana już po sporządzeniu i odczytaniu aktu, zapewne na życzenie samego Szukiewicza. Prawdopodobnie ze względu na jej nietypowe umiejscowienie wykonujący po blisko 25 latach odpis dokumentu ks. Franciszek Zamaszewski nie uwzględnił jej w tym odpisie (podobnie jak formuły ,urzędnik cywilny"), przez co nie znalazła się ona w edycji Przesmyckiego.

Na zakończenie warto jeszcze dodać, że księgę zamyka alfabetyczny regestr, w którym w trzech działach: „urodzeni”, zaślubieni”, „zmarli” odnotowywane są dane osób wpisanych do odpowiednich akt i numery tych dokumentów oraz numery kart, na których są one wpisane (zob. il. 4). Szczęśliwie zachowała się także strona z nazwiskami zaczynającymi się na literę „N” (zob. il. 5). 


\title{
BIBLIOGRAFIA
}

Cyprian Norwid. Wystawa w 125 rocznice urodzin. Katalog, Warszawa 1946.

PAŁYS W., Ślady Norwidów w Dąbrówce, „Studia Norwidiana” 20-21(2002-2003), s. 163-182.

Trojanowiczowa Z., LiJewsKa E., Kalendarz życia i twórczości Cypriana Norwida, t. II: 1861-1883, Poznań 2007.

Trojanowiczowa Z., Dambek Z., Kalendarz życia i twórczości Cypriana Norwida, tom I: 1821-1860, Poznań 2007.

Gomulicki J.W., Cyprian Norwid. Przewodnik po życiu i twórczości, Warszawa 1976.

Z.P. [PRZESMYCKI ZENON], Z notat i dokumentów o C. Norwidzie, „Chimera”8(1904), z. 22/23/24, s. $419-453$.

\section{NIEPUBLIKOWANA PODOBIZNA ORYGINAŁU AKTU URODZENIA CYPRIANA NORWIDA}

\author{
S t r e s z c z e n i e
}

Artykuł prezentuje dotychczas niepublikowany oryginał aktu urodzenia Cypriana Norwida, pochodzący z akt parafii w Dąbrówce. Autor analizuje treść dokumentów archiwalnych i pism samego Norwida, w których poeta nawiązuje do daty swego urodzenia. Sięga również do ustaleń Zenona Przesmyckiego oraz Juliusza Wiktora Gomulickiego.

Słowa kluczowe: akt urodzenia; Dąbrówka; ks. Jan Kanty Matliński.

\section{UNPUBLISHED LIKENESS OF THE ORIGINAL BIRTH CERTIFICATE OF CYPRIAN NORWID}

\section{S u m m a r y}

The article presents an unpublished original of Cyprian Norwid's birth certificate, found in Dąbrówka parish records. The author examines the content of the archival documentation and writings by Norwid himself, in which the poet makes reference to his birth date, as well as looking at findings of Zenon Przesmycki and Juliusz Wiktor Gomulicki.

Key words: birth certificate; Dąbrówka; Father Jan Kanty Matliński.

TOMASZ KORPYSZ - doktor hab., profesor na Wydziale Nauk Humanistycznych Uniwersytetu Kardynała Stefana Wyszyńskiego w Warszawie, kierownik Pracowni Słownika Języka Cypriana Norwida Uniwersytetu Warszawskiego. Adres: ul. Dewajtis 5, 01-815 Warszawa, e-mail: t.korpysz@uksw.edu.pl. 
NIEPUBLIKOWANA PODOBIZNA ORYGINAŁU AKTU URODZENIA CYPRIANA NORWIDA

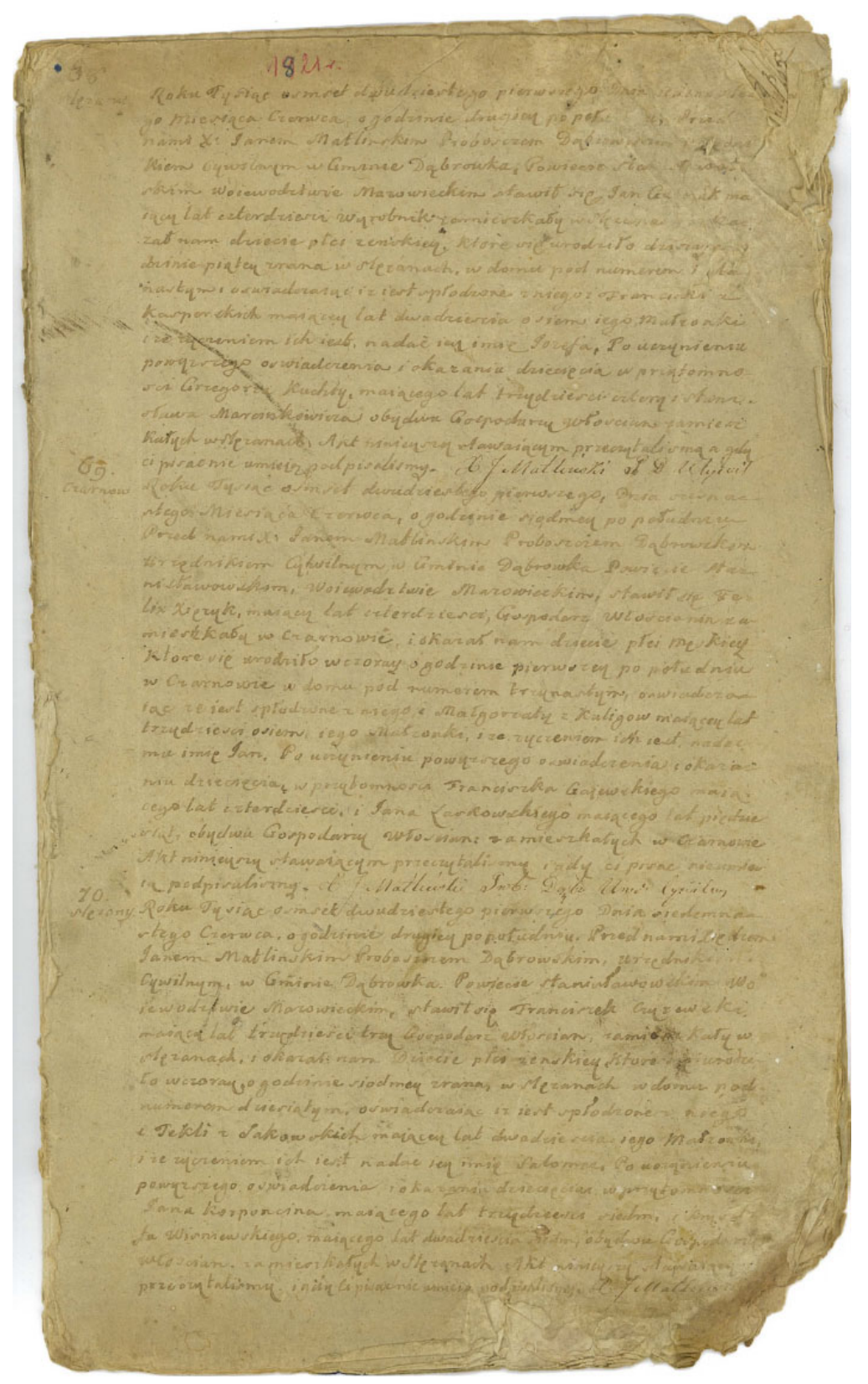

Il. 1. Pierwsza strona zachowanego fragmentu księgi aktów stanu cywilnego z $1821 \mathrm{r}$. 
TOMASZ KORPYSZ

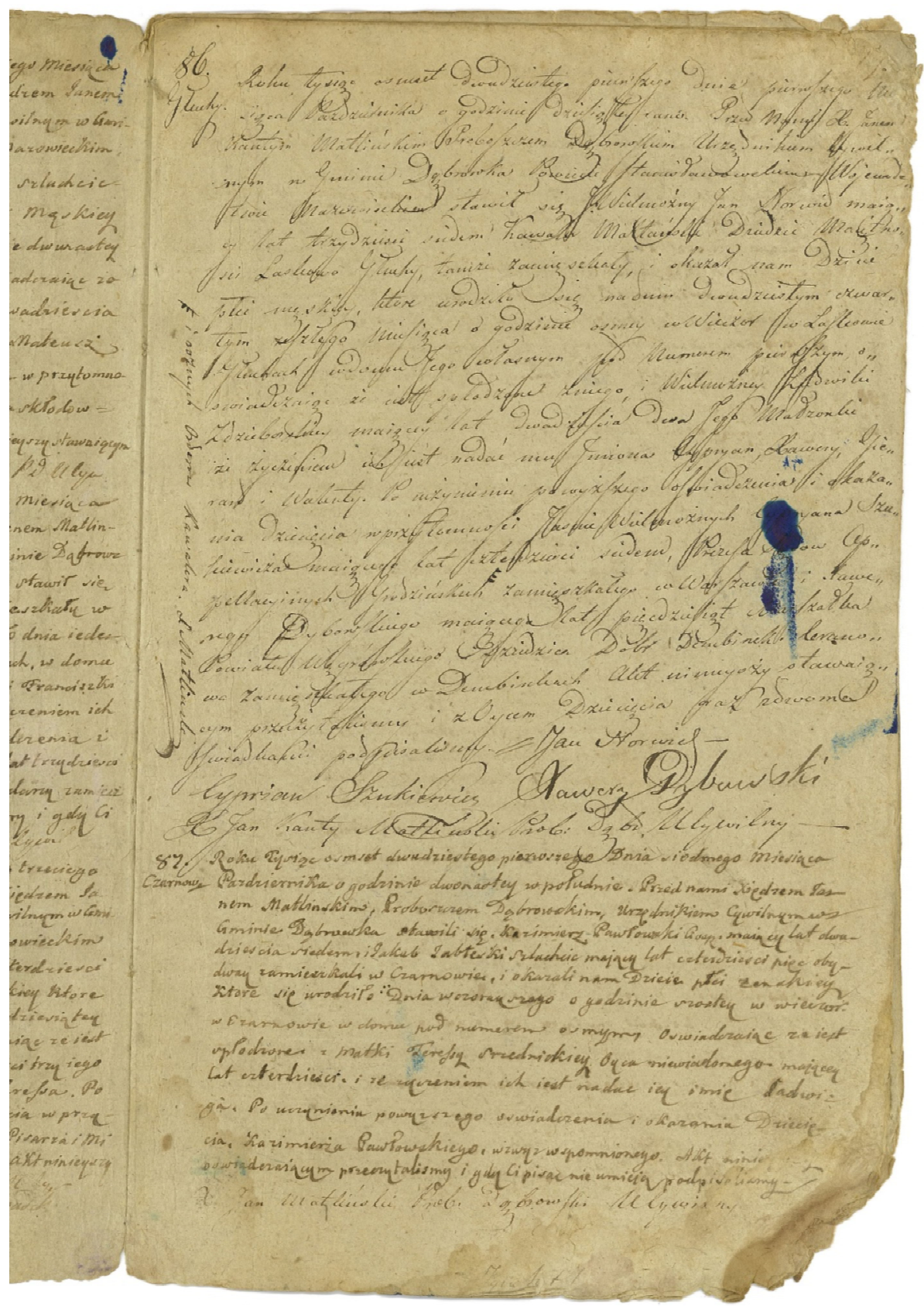

Il. 2. Akt urodzenia Cypriana Norwida 


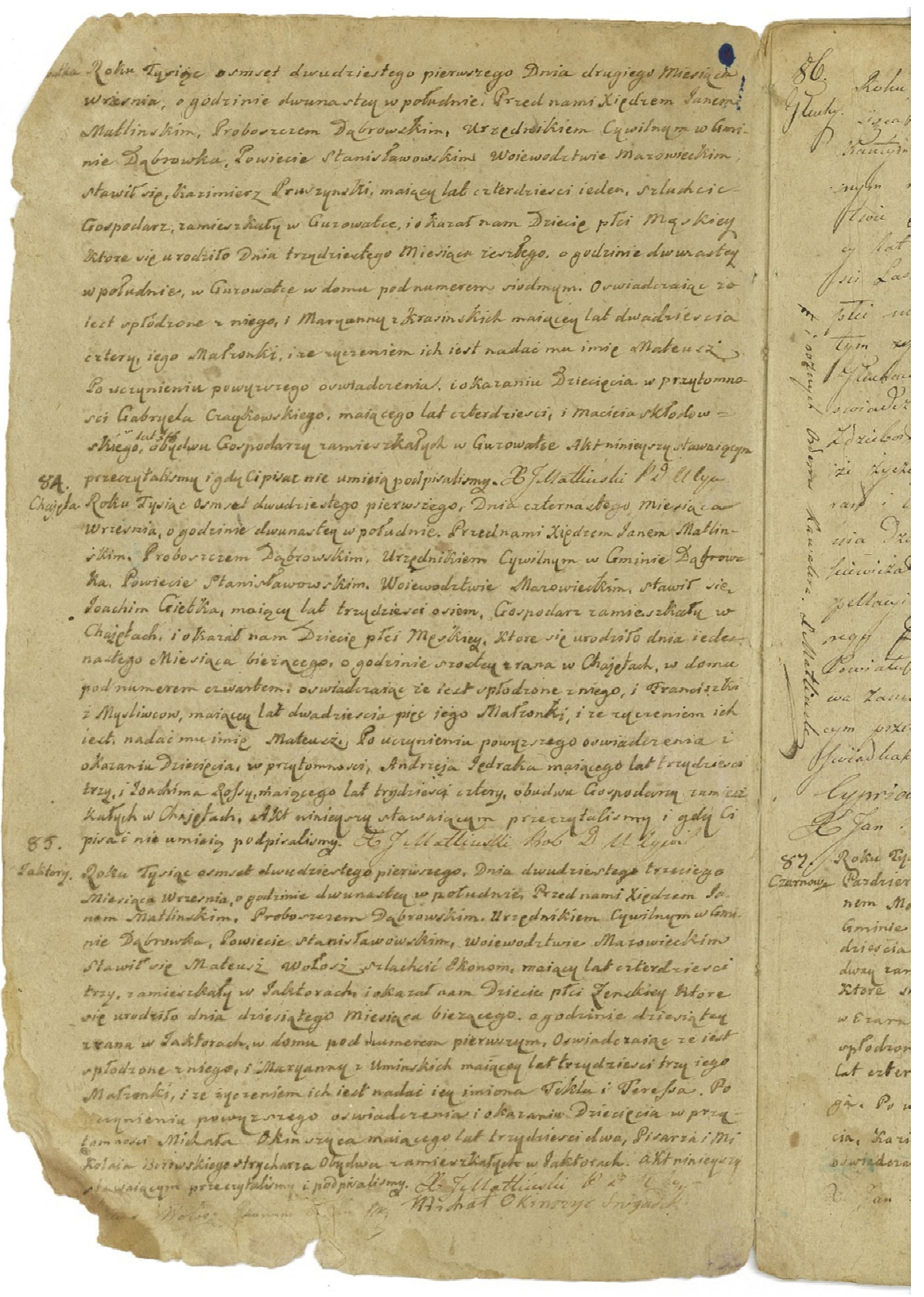

Il. 3. Sąsiednia strona księgi z aktami podpisanymi jedynie przez proboszcza 
TOMASZ KORPYSZ

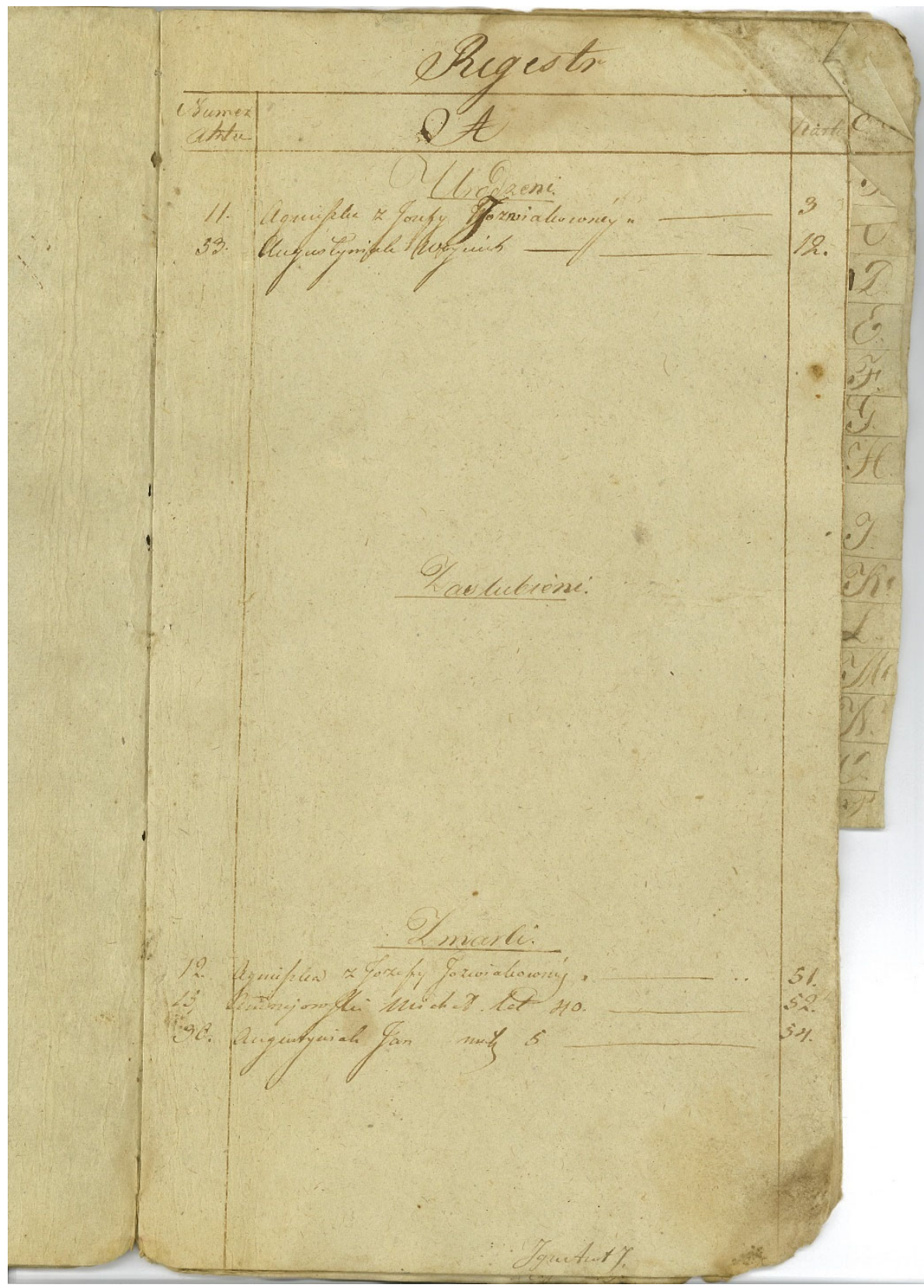

Il. 4. Pierwsza strona regestru 
NIEPUBLIKOWANA PODOBIZNA ORYGINAŁU AKTU URODZENIA CYPRIANA NORWIDA

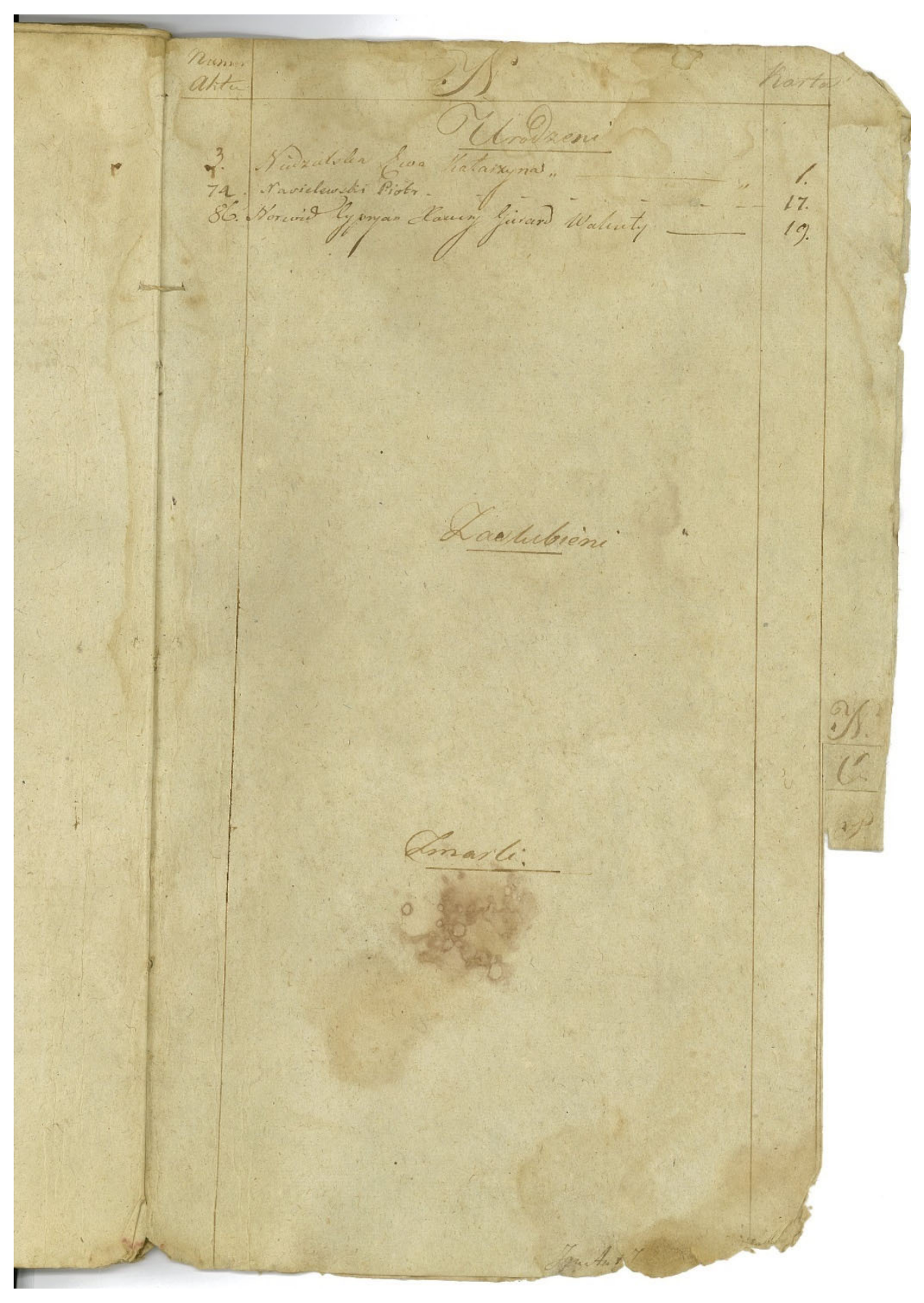

Il. 5. Strona regestru z wpisem dotyczącym poety 